\title{
Medical genetics studies at BGRS conference series
}

\author{
Ancha V. Baranova ${ }^{1,2}$, Mikhail Yu. Skoblov², Elena N. Voropaeva ${ }^{3}$, Piramanayagam Shanmughavel ${ }^{4}$ \\ and Yuriy L. Orlov ${ }^{3,5^{*}}$ \\ From 11th International Multiconference "Bioinformatics of Genome Regulation and StructurelSystems Biology" - BGRSISB- \\ 2018 \\ Novosibirsk, Russia. 20-25 August 2018
}

This Special Issue of BMC Medical Genetics presents the papers materials discussed at the biomedical session of the multi-conference "Bioinformatics of Genome Regulation and Structure $\backslash$ Systems Biology" (BGRS\SB-2018) (http:// conf.bionet.nsc.ru/bgrssb2018/en/). This international biannual conference takes place in Novosibirsk since 1998 gathering professionals in genomics, genetics, and biomedicine. To accompany this Special Issue, other Special Issues in the fields of genomics, bioinformatics, plant biology, evolutionary biology and systems biology are published as a part of following series: BMC Medical Genomics, BMC Bioinformatics, BMC Systems Biology, BMC Evolutionary Biology and BMC Plant Biology [1-4], as well as BMC Genomics and BMC Genetics issues. Medical genetics problems have been discussed in the articles from previous post-conference journal issues [5-8]. In year 2017, respective conference highlights were organized into the Special Issues with reports from Belyaev Readings-2017 memorial event (http://conf.bionet.nsc.ru/ belyaev100/en) [9-12]. Note medical genetics topics from the conference series were presented earlier at BMC Medical Genomics [1, 12] and BMC Neuroscience [9] as well as BMC Genetics $[8,11]$ special issues.

The papers comprising this issue of BMC Medical Genetics were discussed at the BGRS $\backslash S B$-affiliated symposium "Systems Biology and Biomedicine" (SBioMed-2018) (http://conf.bionet.nsc.ru/ishg2018/en/). A brief summary of these papers and related works is outlined below.

We start our Special Issue by the paper by Snezhkina and co-authors discussing novel potential causative genes in carotid paragangliomas [13]. Carotid paragangliomas

\footnotetext{
* Correspondence: orlov@bionet.nsc.ru

${ }^{3}$ Research Institute of Internal and Preventive Medicine - Branch of the Institute of Cytology and Genetics SB RAS, 630090 Novosibirsk, Russia

${ }^{5}$ Novosibirsk State University, 630090 Novosibirsk, Russia

Full list of author information is available at the end of the article
}

are rare neuroendocrine tumors that arise from the paraganglion at the bifurcation of the carotid artery and are responsible for approximately $65 \%$ of all head and neck paragangliomas. Unlike other types of cancer, there is no test that determines benign from malignant tumors. Genetic basis behind the development of these tumors is not fully elucidated, and the molecular mechanisms underlying CPGL pathogenesis remain unclear [14]. Analysis of exome and transcriptome tumor samples allowed Snezhkina et al. to determine novel potential causative genes.

Yurchenko et al. [15] presented the exome-wide survey of the Siberian Caucasian population. This study has compared allele frequencies of Siberian Caucasian and European populations from 1000 Genomes Project and identified significant population differentiation as well as a higher proportion of the Finnish genetic component in the Siberian sample. Several of the allelic differences correspond to medically and pharmacogenetically important genes, and these variants will be studied in future on an expanded dataset with associated clinical data.

Maria Fedorova and colleagues [16] used colon adenocarcinoma TCGA RNA-Seq dataset to show that CpG island methylator phenotype, which is common in carcinomatous malignization of serrated adenomas, is associated with the shift in an energy metabolism and sufficient activation of immune-associated pathways. These findings were confirmed by qRT-PCR validation in additional cohort of patients. The ANDSystem tool for association studies in biomedicine was presented earlier at BMC Systems Biology special issues [17].

Diana Osmanova and her colleagues [18] provide us with insights into involvement of dopaminergic pathways in antipsychotic-induced hyperprolactinemia by uncovering statistically significant association between a certain polymorphic variant of gene MAOB, which 
encodes dopamine catabolizing enzyme and the development of hyperprolactinemia in response to any antipsychotic drug or their combination, and two other, risperidone/paliperidone-responsive variants in SLC6A3, which encodes dopamine transporter. Problem of depression studies were discussed by the same authors' group at their recent article at Frontiers in Genetics [19], also being part of BGRS-2018 special issue.

Therapeutical strategies for anxiety-like behavior treatment continued by the works of Fedotova et al. [20]. Here Julia Fedotova discussed vitamin D3 treatment differentially affect anxiety-like behavior in the old ovariectomized female rats treated with low dose of $17 \beta$-estradiol [21]. After the menopause or surgical removal of ovaries, females are faced with estrogen deficiency, manifested in mood disturbances, such as anxiety and depression. Hormonal replacement therapy used to treat these symptoms has numerous side effects and not always efficient. Fedotova used rat model to evaluate the effects of repeated vitamin D3 administration on anxiety-related behavior in the middle-aged and old female rats with long-term estrogen deficiency. She determined that repeated systemic treatment with vitamin D3 decreased the symptoms on anxiety-like behavior in the old female rats after long-term ovariectomy. Extension of this work for human patients may provide a safe and efficient alternative therapy for many women.

Hence, we present our readers with a wide array of reports describing recent breakthrough in genomics-driven understanding of a molecular pathophysiology of a variety of human disease, covering a spectrum from Mendelian disorders to chronic multifactorial conditions and cancer. At BGRS-2018, the symposium "Systems Biology and Biomedicine" (SBioMed-2018) was also attended by young scientists who gathered in Novosibirsk for a School "Systems Biology and Bioinformatics" (SBB-2018) (http://conf.bionet.nsc.ru/bgrssb2018/en/school/). In previous years, the materials of SBB Schools were published in Special Issues of BMC as well [7, 22]. We invite our readers worldwide to attend our next event - Systems Biology and Bioinformatics Young Scientists School SBB-2019 which will be held in Novosibirsk, Russia 24-28 June 2019 (http://conf.bionet. nsc.ru/sbb2019/en/). Next BGRS\SB-2020 multiconference and biomedical symposium will be organized again in June 2020, in Novosibirsk, Russia.

\section{Acknowledgements}

We are grateful to Professors N.A. Kolchanov, V.V. Klimontov and A.V. Kochetov for organization of the multi-conference, "Systems Biology and Biomedicine" symposium and providing platform for international medical genomics research. We thank the Russian Foundation of Basic Research for the conference organization support, Zhejiang Bioinformatics Society (Prof. Ming Chen) for logistic support of conference participants, Novosibirsk State University, Institute of Cytology and Genetics SB RAS (budget project 03242019-0040) and RFBR the conference support.

The guest editors of the special issue are grateful to the conference committee members and reviewers who helped in the peer-review of the articles as well as in editing and issue preparation: Tatiana Tatarinova (La Verne University, CA, USA), Irina Yushenova (Josephine Bay Paul Center for Comparative Molecular Biology and Evolution, Woods Hole, USA), Oleg Shuvalov and Nikolai Barlev (Institute of Cytology, St.Petersburg, Russia), Petr Slominskiy (Institute of Molecular Genetics, Moscow, Russia), Maria Tikhonova (Institute of Physiology and Basic Medicine, Novosibirsk, Russia), Vladimir Babenko (Institute of Cytology and Genetics SB RAS, Russia), Mariam Muradova and Denis Baranenko (ITMO University, St.Petersburg, Russia), Sergii Tukaiev (National Taras Shevchenko University of Kyiv, Ukraine), Andrei Krivtsov (Dana-Farber Cancer Institute, Boston, USA), Hongyu Yang (Peking University, Shenzhen Hospital, Shenzhen, China), Andre Marakhonov (Medical Genetics Center, Moscow, Russia), Elza Khusnutdinova (Institute of biochemistry and genetics, Ufa, Russia), Ranajit Das (Manipal Academy of Higher Education, Manipal, Karnataka, India).

\section{Funding}

This article did not receive sponsorship for publication.

\section{About this supplement}

This article has been published as part of BMC Medical Genetics Volume 20 Supplement 1, 2019: Selected articles from BGRSISB-2018: medical genetics. The full contents of the supplement are available online at https:// bmcmedgenet.biomedcentral.com/articles/supplements/volume-20supplement-1.

\section{Authors' contributions}

$A V B$ and YLO are guest editors of the special post-conference issues and Program Committee members of BGRSISB-2018 conference. MYS, ENV, PS are Organizing Committee members of "Systems Biology and Biomedicine" symposium at BGRS $\backslash S B-2018$. All the authors read, revised and approved the final manuscript.

\section{Competing interests}

The authors declare that they have no competing interests.

\section{Publisher's Note}

Springer Nature remains neutral with regard to jurisdictional claims in published maps and institutional affiliations.

\section{Author details}

${ }^{1}$ School of Systems Biology, George Mason University, Fairfax, VA, USA. ${ }^{2}$ Research Centre for Medical Genetics, 115478 Moscow, Russia. ${ }^{3}$ Research Institute of Internal and Preventive Medicine - Branch of the Institute of Cytology and Genetics SB RAS, 630090 Novosibirsk, Russia. ${ }^{4}$ Bharathiar University, Coimbatore, Tamilnadu 641046, India. ${ }^{5}$ Novosibirsk State University, 630090 Novosibirsk, Russia.

Published: 9 April 2019

\section{References}

1. Baranova AV, Klimontov W, Letyagin AY, Orlov YL. Medical genomics research at BGRS-2018. BMC Medical Genomics. 2019;12(Suppl 2). https:// doi.org/10.1186/s12920-019-0480-0.

2. Orlov YL, Hofestädt R, Baranova AV. Systems biology research at BGRS-2018. BMC Systems Biology. 2019;13(Suppl 1). https://doi.org/10.1186/s12918-019-0685-z.

3. Tatarinova TV, Chen M, Orlov YL. Bioinformatics research at BGRS-2018. BMC Bioinformatics. 2019;20(Suppl 1):33. https://doi.org/10.1186/s12859-018-2566-7.

4. Orlov YL, Baranova AV, Kolchanov NA, Moroz LL. Evolutionary biology and biodiversity research at BGRS-2018. BMC Evolutionary Biology. 2019;19(Suppl 1). https://doi.org/10.1186/s12862-019-1368-5.

5. Orlov YL, Baranova AV, Hofestadt R, Kolchanov NA. Computational genomics at BGRSISB-2016: introductory note. BMC Genomics. 2016; 17(Suppl 14):996.

6. Baranova AV, Orlov YL. Evolutionary biology at BGRS ISB-2016. BMC Evol Biol. 2017;17(Suppl 1):21

7. Orlov YL, Kolchanov NA, Hofestädt R, Wong L. Editorial - bioinformatics development at the BGRSISB conference series: 10th anniversary. J Bioinform Comput Biol. 2017;15(2):1702001.

8. Orlov YL, Baranova AV, Markel AL. Computational models in genetics at BGRSISB-2016: introductory note. BMC Genet. 2016;17(Suppl 3):155. 
9. Orlov YL, Moroz LL, Baranova AV. Neuroscience researches at Belyaev conference-2017. BMC Neurosci. 2018;19(Suppl 1):14.

10. Orlov YL, Baranova AV, Salina EA. Computational plant bioscience at BGRSISB-2016: introductory note. BMC Plant Biol. 2016;16(Suppl 3):243.

11. Orlov YL, Baranova AV, Tatarinova TV, Kolchanov NA. Genetics at Belyaev conference - 2017: introductory note. BMC Genet. 2017;18(Suppl 1):116.

12. Orlov YL, Fernandez-Masso JR, Chen M, Baranova AV. Medical genomics at Belyaev conference - 2017. BMC Med Genet. 2018;11(Suppl 1):11.

13. Snezhkina AV, Lukyanova EN, Zaretsky AR, Kalinin DV, Pokrovsky AV, Golovyuk AL, Krasnov GS, Fedorova MS, Pudova EA, Kharitonov SL, Melnikova NV, Alekseev BY, Kiseleva MV, Kaprin AD, Dmitriev AA, Kudryavtseva AV. Novel potential causative genes in carotid paragangliomas. BMC Medical Genetics. 2019;20(Suppl 1). https://doi.org/10. 1186/s12881-019-0770-6.

14. Zhikrivetskaya SO, Snezhkina AV, Zaretsky AR, Alekseev BY, Pokrovsky AV, Golovyuk AL, et al. Molecular markers of paragangliomas/ pheochromocytomas. Oncotarget. 2017;8(15):25756-82.

15. Yurchenko AA, Yudin NS, Voevoda MI. Exome-wide survey of the Siberian Caucasian population. BMC Medical Genetics. 2019;20(Suppl 1). https://doi org/10.1186/s12881-019-0772-4

16. Fedorova MS, Krasnov GS, Lukyanova EN, Zaretsky AR, Dmitriev AA, Melnikova NV, Moskalev AA, Kharitonov SL, Pudova EA, Guvatova ZG, Kobelyatskaya AA, Ishina IA, Slavnova EN, Lipatova AV, Chernichenko MA, Sidorov DV, Popov AY, Kiseleva MV, Kaprin AD, Snezhkina AV, Kudryavtseva AV. The CIMP-high phenotype is associated with energy metabolism alterations in colon adenocarcinoma. BMC Medical genetics. 2019;20(Suppl 1). https://doi.org/10. 1186/s12881-019-0771-5.

17. Ivanisenko VA, Saik OV, Ivanisenko NV, Tiys ES, Ivanisenko TV, Demenkov PS, et al. ANDSystem: an Associative Network Discovery System for automated literature mining in the field of biology. BMC Syst Biol. 2015;9 Suppl 2:S2.

18. Osmanova DZ, Freidin MB, Fedorenko OY, Pozhidaev IV, Boiko AS, Vyalova NM, Tiguntsev W, Kornetova EG, Loonen A, Semke AV, Wilffert B, Bokhan NS, Ivanova SA. A pharmacogenetic study of patients with schizophrenia from West Siberia gets insight into dopaminergic mechanisms of antipsychotic-induced hyperprolactinemia. BMC Medical genetics. 2019; 20(Suppl 1). https://doi.org/10.1186/s12881-019-0773-3.

19. Aftanas LI, Anisimenko MS, Berdyugina DA, Garanin AY, Maximov VN, Voevoda MI, Vyalova NM, Bokhan NA, Ivanova SA, Danilenko KV, Kovalenko SP. SIRT1 allele frequencies in depressed patients of European descent in Russia. Front Genet. 2019;9:686. https://doi.org/10.3389/fgene.2018.00686.

20. Fedotova J, Kubatka P, Büsselberg D, Shleikin AG, Caprnda M, Dragasek J, Rodrigo L, Pohanka M, Gasparova I, Nosal V, Opatrilova R, Qaradakhi T, Zulli A, Kruzliak P. Therapeutical strategies for anxiety and anxiety-like disorders using plant-derived natural compounds and plant extracts. Biomed Pharmacother. 2017;95:437-46.

21. Fedotova J. Vitamin D3 treatment differentially affect anxiety-like behavior in the old ovariectomized female rats and old ovariectomized female treated with low dose of 17ß-estradiol. BMC Medical Genetics. 2019; 20(Suppl 1). https://doi.org/10.1186/s12881-019-0774-2.

22. Baranova AV, Orlov YL. The papers presented at 7th young scientists school "systems biology and bioinformatics" (SBB'15): introductory note. BMC Genet. 2016;17(Suppl 1):20.

Ready to submit your research? Choose BMC and benefit from:

- fast, convenient online submission

- thorough peer review by experienced researchers in your field

- rapid publication on acceptance

- support for research data, including large and complex data types

- gold Open Access which fosters wider collaboration and increased citations

- maximum visibility for your research: over $100 \mathrm{M}$ website views per year

At $\mathrm{BMC}$, research is always in progress.

Learn more biomedcentral.com/submissions 